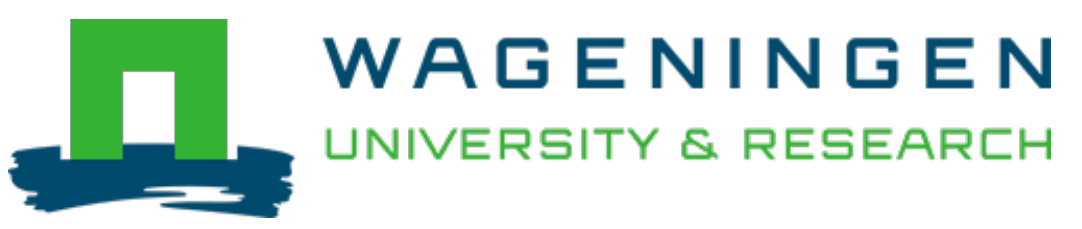

\title{
Effect of acidification on the microbiological composition and performance of tempe starter.
}

\author{
Food Microbiology \\ Tünçel, G.; Nout, M.J.R.; Rombouts, F.M. \\ https://doi.org/10.1016/s0740-0020(89)80035-8
}

This publication is made publicly available in the institutional repository of Wageningen University and Research, under the terms of article $25 \mathrm{fa}$ of the Dutch Copyright Act, also known as the Amendment Taverne. This has been done with explicit consent by the author.

Article 25 fa states that the author of a short scientific work funded either wholly or partially by Dutch public funds is entitled to make that work publicly available for no consideration following a reasonable period of time after the work was first published, provided that clear reference is made to the source of the first publication of the work.

This publication is distributed under The Association of Universities in the Netherlands (VSNU) 'Article $25 \mathrm{fa}$ implementation' project. In this project research outputs of researchers employed by Dutch Universities that comply with the legal requirements of Article $25 \mathrm{fa}$ of the Dutch Copyright Act are distributed online and free of cost or other barriers in institutional repositories. Research outputs are distributed six months after their first online publication in the original published version and with proper attribution to the source of the original publication.

You are permitted to download and use the publication for personal purposes. All rights remain with the author(s) and / or copyright owner(s) of this work. Any use of the publication or parts of it other than authorised under article $25 \mathrm{fa}$ of the Dutch Copyright act is prohibited. Wageningen University \& Research and the author(s) of this publication shall not be held responsible or liable for any damages resulting from your (re)use of this publication.

For questions regarding the public availability of this publication please contact openscience.library@wur.nl 
Food Microbiology, 1989, 6, 37-43

\title{
Effect of acidification on the microbiological composition and performance of tempe starter
}

\author{
G. Tünçel ${ }^{\star}$, M. J. R. Noutt and F. M. Rombouts \\ Department of Food Science, Agricultural University, Wageningen, \\ The Netherlands
}

Received 12 July 1988

Using rice and soya-beans as raw materials, the effects of: (i) (fermentative) acidification of the substrate, (ii) cross-contamination with acidifying microflora of the soaked substrate and (iii) the method of spore extraction were investigated. Microbiological analyses of fresh and stored starters, and of the resulting soya-bean tempe were carried out. The acceptability of fresh tempe was also evaluated. Rice-based starters yielded tempe of higher acceptability but had a shorter shelf-life (2.5 months) than soya-bean based starters ( 7 months). Fermentative acidification of raw materials resulted in starters with higher counts of fungal spores and lower counts of bacteria. Starters made with cross-contaminated raw materials resulted in tempe of highest acceptability when fermentatively acidified soya-beans were used for tempe manufacture. Starter extraction by straining of fungal spores was compared with grinding the total mass of moulded substrate, and was considered inappropriate in view of its low yield compared to the grinding method. It is concluded that fermentative acidification of raw materials prior to the manufacture of starters and tempe contributes to their microbiological safety and acceptability. The latter can be increased by lactic acid bacteria which may be introduced by the starter or by cross-contamination with fermentatively acidified soaking water.

\section{Introduction}

Tempe, mostly manufactured from soyabeans, consists of a firm cake of beans and fungal mycelium, obtained by solid substrate fermentation of soaked and cooked raw material. The manufacturing process was reviewed by $\mathrm{K}_{0}$ and Hesseltine (1979).

Originating in Indonesia, tempe meets an increasing interest in other regions including the US (Wang 1984) and Europe (Berghofer 1987). In addition,

\footnotetext{
* Present address: Faculty of Engineering, Ege University, Izmir, Turkey.

$†$ Correspondence should be addressed to: M. J. R. Nout, Department of Food Science, Bomenweg 2, 6703 HD Wageningen, The Netherlands.
}

0740-0020/89/010037+07\$02.07/0 tempe manufacture could be an appropriate method (Steinkraus 1978) for small- and medium-scale processing of locally available legumes and cereals into wholesome products of high nutritional value in developing countries (Djurtoft and Nielsen 1983).

In Indonesia, tempe is a widely consumed protein component of the diet. Consequently, it is daily available in most markets and has a rapid turn-over. Usually, the fresh product is prepared and consumed the same dav it has been purchased. However, in societies where tempe is a minor product, distribution and marketing may require considerable time. Since fresh tempe has a limited shelf-life, such delays can cause spoilage or loss of acceptability. During a survey

(C) 1989 Academic Press Limited 
of the microbiological composition of tempe sold in the Netherlands (Samson et al. 1987), counts of Enterobacteriaceae were $\geq 10^{6} \mathrm{~g}^{-1}$ in $60 \%$ of all samples; Staphylococcus aureus and Bacillus cereus counts were $\geq 10^{5} \mathrm{~g}^{-1}$ in 13 and $11 \%$ of all samples, respectively. The poor bacterial quality of such samples can be related primarily to the conditions prevailing during the tempe fermentation, and secondarily to inadequate storage conditions.

Several attempts have been made to preserve tempe, e.g. by packaging (Leviton 1984), parboiling and freezing (Shurtleff and Aoyagi 1979) or dehydration (Steinkraus et al. 1965). Such added technologies increase the consumer price and decrease the competitiveness with alternative products of equivalent protein content such as meat offals. This is of particular importance for lowincome consumer groups in developing countries.

Our aim is to achieve optimum product acceptability, shelf-life and microbiological composition by applying environmental conditions favouring tempe formation but inhibiting the development of undesirable microflora. In this context we reported earlier that accelerated souring of soya-beans by lactic acid fermentation inhibits the growth of Enterobacteriaceae, B. cereus (Nout et al. $1987 \mathrm{a}, \mathrm{b}$ ) and $S$. aureaus (Nout et al. in press) during tempe manufacture. In addition, the combined use of acidified cooked beans and fermentation conditions favouring lactobacilli contributed positively to the acceptability of the final product (Nout et al. 1987a).

Our standard tempe fermentation conditions were designed to be representative for the traditional Indonesian method as well as the commercial production in the Netherlands. The strain of Rhizopus oligosporus used (NRRL 5905), isolated from Indonesian tempe, has an optimum growth temperature of $33^{\circ} \mathrm{C}$ whereas its maximum temperature for growth is $42^{\circ} \mathrm{C}$. In Indonesia, incubation temperatures vary between $20-30^{\circ} \mathrm{C}$ (Ko and Hesseltine 1979). Earlier experiments in our laboratory had shown that incubation at $30^{\circ} \mathrm{C}$ for $40-44 \mathrm{~h}$ gave optimum tempe acceptability and shelflife. At this incubation temperature, the heat generated by the growing mould causes a temperature increase up to approx. $40^{\circ} \mathrm{C}$ in the centre of the tempe cakes.

In Indonesia, the tempe fermentation is started with 'usar' (Soetarno Hadisepoetro et al. 1979), usually consisting of Hibiscus ('waru') leaves covered with a mixed microflora. This includes the fungus Rhizopus oligosporus which is regarded as essential for tempe formation (Hesseltine 1965). Due to the simple manufacturing process, the mixed microbiological composition of 'usar' is difficult to control. For this reason, and for convenient use in medium- and largerscale tempe manufacture, several authors (Hesseltine et al. 1976, Ko 1985, Lindajati Tanuwidjaja and Roestamsjah 1985) proposed processes for the production of optimized tempe starters consisting of pure cultures of $R$. oligosporus grown on rice or soya-beans. Little attention has been paid to the bacteriological composition of such pure or semi-pure culture starters made under laboratory conditions.

Obviously, the microflora development during the tempe fermentation will be influenced by several factors including the incubation temperature, the $a_{w}$ of the substrate, and the microbial load accompanying $R$. oligosporus in a tempe starter. Using our standardised process with $30^{\circ} \mathrm{C}$ incubation and with substrate from which adhering water was removed by adequate evaporation, we investigated if the principle of accelerated acidification (Nout et al. 1987a) could be 
applied to reduce undesirable microbial development during starter manufacture. In addition, the effect of experimental starters on the acceptability and microbiological composition of fresh tempe was evaluated.

\section{Materials and Methods \\ Culture}

Rhizopus oligosporus NRRL5905 was grown and maintained on malt extract agar (MEA, Oxoid CM 59) slants. Incubation was at $30^{\circ} \mathrm{C}$ for 1 week, and storage at $5^{\circ} \mathrm{C}$.

Usar

Traditional tempe starter ('usar') was obtained fresh from a manufacturer at Malang, Indonesia. A composite sample of 3 leaves (average weight $3.5 \mathrm{~g}$ per leaf) was used for analysis.

\section{Analysis}

Sample preparation, enumeration of total aerobic bacteria, Enterobacteriaceae, yeasts, lactic acid bacteria, bacterial spores and Bacillus cereus, as well as reporting of counts was described previously (Nout et al. 1987b).

Fungal propagules: pour plates in rose bengal chloramphenicol agar base (Oxoid CM 549) with addition of $0.2 \mathrm{~g} \mathrm{l}^{-1}$ Ruse Bengal (Fluka AG, Switzerland) and, after sterilization, $100 \mathrm{mg}$ chloramphenicol/800 $\mathrm{ml}$ basal medium. Incubation was at $30^{\circ} \mathrm{C}$ for $3-5$ days.

Staphylococcus aureus: surface count plates in Baird-Parker agar (BP medium base, Gibco 152-0320) with addition of $50 \mathrm{ml}$ egg yolk tellurite enrichment (Oxoid 077973-1) per $950 \mathrm{ml}$ basal medium after sterilization. Incubation was at $35^{\circ} \mathrm{C}$ for $24 \mathrm{~h}$.

\section{Tempe quality}

The assessment of tempe acceptability was based upon exterior colour, fungal penetration, firmness, smell and $\mathrm{pH}$ and was carried out according to guidelines given previously (Nout et al. 1985).

\section{Starter manufacture}

Starter were prepared using two substrates, i.e. soya-beans (dehulled by dry abrasion) and brown rice. The basic process consisted of soaking the substrates for $24 \mathrm{~h}$; draining and discarding the soak water; rinsing the substrates twice with tapwater; boiling in 3 times (soya-beans) or 1.5 times (rice) their weight of tapwater for $20 \mathrm{~min}$; draining and discarding the boiling water; spreading the substrates in a $1 \mathrm{~cm}$ thick layer on wire mesh to cool during $40 \mathrm{~min}$; inoculating with $0.3 \%$ v/w spore suspension of $R$. oligosporus NRRL5905 prepared as described earlier (Nout et al. 1987b); incubation in perforated containers at $30^{\circ} \mathrm{C}$ for $48 \mathrm{~h}$ (soya-beans) or 1 week (rice); drying with a fan-dryer at $50^{\circ} \mathrm{C}$ for $5.5 \mathrm{~h}$ (soya-beans) until approx. $9 \%$ moisture content. Due to the extended incubation required to obtain adequate sporulation in rice-based starters, the latter had a postincubation moisture content of 9-12\% and were not given additional drying treatment. The dried material was either ground whole, or was passed through a strainer to obtain a dry spore concentrate.

The following experimental treatments were applied. (A) and (B): soaking at $25^{\circ} \mathrm{C}$ with $1 \%$ v/w soak water from a stabilized acidifying soak obtained as described earlier (Nout et al. 1987a). In (B), $0.6 \% \mathrm{v} / \mathrm{w}$ of the soak water mentioned above was added during the inoculation with $R$. oligosporus; $(\mathrm{C})$; soaking at $5^{\circ} \mathrm{C}$ in tapwater acidified with $1.5 \% \mathrm{w} / \mathrm{w}$ lactic acid and $0.3 \% \mathrm{w} / \mathrm{w}$ acetic acid (soya-beans) or $0.25 \%$ lactic acid and $0.05 \%$ $\mathrm{w} / \mathrm{w}$ acetic acid (rice) in order to achieve acidity and $\mathrm{pH}$ prevailing in raw materials soaked according to procedure $\mathrm{A}(\mathrm{pH} 4.55$ in soya-beans and $\mathrm{pH} 4.70$ in rice); (D): soaking at $5^{\circ} \mathrm{C}$ in tapwater. Storage of all finished starters was at $5^{\circ} \mathrm{C}$.

\section{Tempe manufacture}

Tempe was made with soya-beans soaked in 3 times their weight of tapwater under 2 different conditions, i.e. (I) for $24 \mathrm{~h}$ at $5^{\circ} \mathrm{C}$ to avoid microbial action. These beans had pH values of 6.0-6.5 after soaking; and (II) for 24 $\mathrm{h}$ at $25^{\circ} \mathrm{C}$ with addition of $1 \% \mathrm{v} / \mathrm{w}$ of soaking water from a soak with stable acidification obtained as described earlier (Nout et al. $1987 \mathrm{a})$, resulting in soaked beans with $\mathrm{pH}$ values of $4 \cdot 0-4 \cdot 5$.

After soaking, the soya-beans were processed into tempe as described previously (Nout et al. 1987a).

\section{Results and Discussion}

Table 1 summarizes the microbiological composition of the starters obtained, and of a composite sample of traditional 'usar' leaves. Rice (3) yielded starters 
Table 1. Microbiological composition of tempe starters $\left(\log \mathrm{cfu} \mathrm{g}^{-1}\right)$.

\begin{tabular}{|c|c|c|c|c|c|c|}
\hline Starters & $\begin{array}{l}\text { Total } \\
\text { aerobic }\end{array}$ & $\begin{array}{c}\text { Aerobic } \\
\text { bacterial } \\
\text { spores }\end{array}$ & $\begin{array}{c}\text { Entero- } \\
\text { bacteriaceae }\end{array}$ & $\begin{array}{c}\text { Lactic } \\
\text { acid } \\
\text { bacteria }\end{array}$ & Yeasts & Moulds \\
\hline $1 \mathrm{~A}^{\mathrm{a}}$ & $2 \cdot 60$ & $2 \cdot 00$ & $<1.70$ & $2 \cdot 85$ & $<1.70$ & $8 \cdot 64$ \\
\hline $1 B$ & $6 \cdot 38$ & $4 \cdot 85$ & $3 \cdot 36$ & $6 \cdot 54$ & $<1 \cdot 70$ & $8 \cdot 15$ \\
\hline $1 \mathrm{C}$ & $5 \cdot 04$ & $2 \cdot 48$ & $<1.70$ & $4 \cdot 94$ & $<1 \cdot 70$ & $8 \cdot 36$ \\
\hline $1 \mathrm{D}$ & $8 \cdot 40$ & $6 \cdot 70$ & $<1.70$ & $6 \cdot 20$ & $<1.70$ & $7 \cdot 38$ \\
\hline $2 \mathrm{~A}$ & $5 \cdot 28$ & $2 \cdot 00$ & $<1 \cdot 70$ & $4 \cdot 34$ & $<1 \cdot 70$ & $8 \cdot 28$ \\
\hline $2 \mathrm{~B}$ & $7 \cdot 70$ & $5 \cdot 28$ & $<1 \cdot 70$ & $7 \cdot 78$ & $<1 \cdot 70$ & $8 \cdot 20$ \\
\hline $2 \mathrm{C}$ & $\mathrm{ND}^{\mathrm{b}}$ & $6 \cdot 48$ & $<1 \cdot 70$ & $6 \cdot 65$ & $<1 \cdot 70$ & $7 \cdot 95$ \\
\hline $2 \mathrm{D}$ & 8.53 & $6 \cdot 48$ & $<1.70$ & $7 \cdot 36$ & $<1.70$ & $7 \cdot 15$ \\
\hline $3 \mathrm{~A}$ & $2 \cdot 30$ & $2 \cdot 30$ & $<1.70$ & $<1.70$ & $<1.70$ & $8 \cdot 20$ \\
\hline $3 B$ & $6 \cdot 04$ & $1 \cdot 78$ & $3 \cdot 30$ & $4 \cdot 63$ & $<1.70$ & $7 \cdot 99$ \\
\hline $3 \mathrm{C}$ & $4 \cdot 65$ & $4 \cdot 49$ & $<1.70$ & $4 \cdot 48$ & $<1 \cdot 70$ & $7 \cdot 61$ \\
\hline $3 \mathrm{D}$ & 4.00 & $3 \cdot 30$ & $<1.70$ & $3 \cdot 11$ & $<1 \cdot 70$ & $7 \cdot 64$ \\
\hline 'Usar' & $7 \cdot 28$ & $3 \cdot 15$ & 7.00 & $6 \cdot 60$ & $6 \cdot 46$ & $8 \cdot 20$ \\
\hline
\end{tabular}

" 1 = soya-bean grown, strained; $2=$ soya-bean grown, ground; $3=$ rice grown, ground; $\mathrm{A}=$ substrate acidified by fermentation; $\mathrm{B}=$ same as $\mathrm{A}$, with addition of acidified soak water; $\mathrm{C}=$ substrate acidified with lactic and acetic acids; $D=$ neutral substrate.

b $\mathrm{ND}=$ not determined.

with lower numbers of contaminating bacteria than soya-beans (2). The numbers of viable fungal spores in rice-based starters $3 \mathrm{~A}$ and $3 \mathrm{~B}$ were similar to those obtained by Lindajati Tanuwidjaja and Roestamsjah (1985). Lower bacterial counts in rice-based starters could result from reduced nutrient availability, but also from the gradual dehydration taking place during the longer incubation of rice. The resulting $a_{w}$ might have been less favourable for bacterial growth. Interestingly, Wang et al. (1975) reported that the moisture content of raw material should be $34-48 \%$ for maximum fungal activity of $R$. oligosporus starter, depending on substrate used. However, they did not study the bacterial development in those starters.

Using soya-beans, the straining method (1) gave slightly higher mould counts with somewhat less contaminating bacteria. However, the weight yield of starter produced by straining was only 5-10\% of the yield of ground starter. The straining method has been recommended (Shurtleff and Aoyagi 1979) to obtain starter of high quality and long shelf-life. Although the bacterial counts are indeed lower, they are still considerable; this and the low yield make straining less appropriate.

In all cases, procedure A yielded the highest concentration of mould propagules, with the lowest number of bacteria. As could be expected there was less bacterial growth with $\mathrm{A}$ due to the low initial $\mathrm{pH}$ of the beans. However, from these results it cannot be concluded whether the higher yield of fungal spores is due to decreased bacterial competition or to other factors (e.g. pH) which may stimulate sporulation.

Procedure $\mathrm{C}$ was carried out to simulate the combined effect of lactic and acetic acids, and $\mathrm{pH}$ prevailing in beans prepared according to $\mathrm{A}$. The resulting starter contained higher bacterial and lower fungal counts. This implies that organic acids and $\mathrm{pH}$ are not the only environmental factors determining the ecological niche in $\mathrm{C}$ occupied by bacteria.

Procedure B was carried out to enforce 
a cross-contamination from the soak water to the cooked beans via the starter. It is thus not surprising to find relatively high numbers of acid tolerant lactic acid bacteria, but also some Enterobacteriaceae.

Procedure $\mathrm{D}$ yielded the lowest fungal activity. It had been carried out as a comparison to $\mathrm{C}$, in order to assess the effect of the combined acidity and $\mathrm{pH}$. Only in strained soya-beans (1) did acidity have the expected reducing effect on total aerobic bacteria and bacterial spore counts. This underlines the earlier suggestion that additional environmental factors are responsible for the reduced bacterial counts in A.

Compared with the experimental starters, the traditional 'usar' leaves had very high counts of Enterobacteriaceae and yeasts. Other counts, including fungal spores, were of the order of magnitude of the experimental starters. The occurrence of Enterobacteriaceae and yeasts on 'usar' may be explained by their common presence on plant material. However, further research is required to assess the influence of these organisms on the quality of tempe.
Table 2 summarizes the effect of storage on the fungal activity of the experimental starters. The viability of soya-bean-based starters $1 \mathrm{~A}, 2 \mathrm{~A}$ and $2 \mathrm{C}$ was hardly affected by 7 months storage, even at room temperature. Starter $2 B$ also had a stable count of fungal spores after an initial decrease. Rice-based starters $3 \mathrm{~A}$ and $3 \mathrm{D}$ retained most of their activity after 2.5 months but had lost $80 \%$ of their viability after 4.5 months of storage at room temperature.

Table 3 summarizes the microbiological composition of soya-bean tempe using neutral (I) and fermentatively acidified (II) beans. Since the performance of the mixed microflora of 'usar' leaves cannot be compared with that of the pure culture starters, we did not include 'usar' in the experimental tempe manufacture.

From a microbiological point of view, starters prepared using procedure $\mathrm{A}$ and those based on ground soya-beans (2) gave the best results. In addition, tempe made with acidified beans (II) had lower counts of accompanying bacteria. These data confirm the beneficial effect of fermentative acidification of raw material on the bacteriological composi-

Table 2. Influence of storage on fungal spore count of experimental tempe starters ( $\log \mathrm{cfu}^{-1}$ ).

\begin{tabular}{|c|c|c|c|c|c|c|c|}
\hline \multirow{2}{*}{$\begin{array}{l}\text { Storage time } \\
\text { (months): } \\
\text { Storage } \\
\text { temperature }\left({ }^{\circ} \mathrm{C}\right):\end{array}$} & \multirow[t]{2}{*}{0} & \multicolumn{2}{|c|}{$2 \cdot 5$} & \multicolumn{2}{|c|}{$4 \cdot 5$} & \multicolumn{2}{|c|}{7} \\
\hline & & 5 & 21 & 5 & 21 & 5 & 21 \\
\hline \multicolumn{8}{|l|}{ Starters } \\
\hline $1 \mathrm{~A}^{a}$ & $8 \cdot 64$ & $8 \cdot 45$ & $8 \cdot 40$ & 8.75 & $8 \cdot 72$ & $N^{b}$ & $8 \cdot 70$ \\
\hline $2 \mathrm{~A}$ & $8 \cdot 28$ & $7 \cdot 92$ & $7 \cdot 98$ & 8.08 & $8 \cdot 48$ & $7 \cdot 92$ & 8.20 \\
\hline $2 \mathrm{~B}$ & $8 \cdot 20$ & $7 \cdot 66$ & $7 \cdot 58$ & $7 \cdot 56$ & $7 \cdot 81$ & $7 \cdot 69$ & $7 \cdot 78$ \\
\hline $2 \mathrm{C}$ & $7 \cdot 95$ & $7 \cdot 86$ & $7 \cdot 76$ & 8.04 & $8 \cdot 04$ & $7 \cdot 89$ & $7 \cdot 99$ \\
\hline $3 \mathrm{~A}$ & $8 \cdot 20$ & $7 \cdot 83$ & $7 \cdot 83$ & $7 \cdot 80$ & $7 \cdot 51$ & ND & $\mathrm{ND}$ \\
\hline $3 \mathrm{D}$ & $7 \cdot 64$ & $7 \cdot 54$ & $7 \cdot 62$ & $7 \cdot 46$ & 6.94 & ND & ND \\
\hline
\end{tabular}

a See Table 1 for explanation of sample codes.

${ }^{\mathrm{b}} \mathrm{ND}=$ not determined. 
Table 3. Microbiological composition $\left(\log \mathrm{cfu}^{-1}\right)$ and acceptability score of tempe.

\begin{tabular}{|c|c|c|c|c|c|c|c|}
\hline Starters & $\begin{array}{l}\text { Soya-bean } \\
\text { pre- } \\
\text { treatment }\end{array}$ & $\begin{array}{c}\text { Lactic } \\
\text { acid } \\
\text { bacteria }\end{array}$ & $\begin{array}{c}\text { Micro- } \\
\text { coccaceae }\end{array}$ & S. aureus & B. cereus & $\begin{array}{c}\text { Entero- } \\
\text { bacteriaceae }\end{array}$ & $\begin{array}{l}\text { Acceptability } \\
\text { (mean of } \\
\text { scores) }\end{array}$ \\
\hline \multirow[t]{2}{*}{$1 \mathrm{~A}^{\mathrm{a}}$} & $\mathrm{I}^{\mathrm{b}}$ & $7 \cdot 81$ & $7 \cdot 36$ & $<2.70$ & $<2 \cdot 70$ & $<1.70$ & $7 \cdot 4$ \\
\hline & II & $6 \cdot 26$ & $2 \cdot 60$ & $<2 \cdot 70$ & $<2.70$ & $<1.70$ & $6 \cdot 2$ \\
\hline \multirow[t]{2}{*}{$1 B$} & I & 8.98 & $8 \cdot 30$ & $<2.70$ & $4 \cdot 81$ & $7 \cdot 54$ & $6 \cdot 0$ \\
\hline & II & $8 \cdot 75$ & $6 \cdot 70$ & $<2 \cdot 70$ & $<2 \cdot 70$ & $6 \cdot 68$ & $5 \cdot 2$ \\
\hline \multirow[t]{2}{*}{$1 \mathrm{C}$} & I & $8 \cdot 79$ & $7 \cdot 18$ & $<2.70$ & $<2 \cdot 70$ & $6 \cdot 40$ & $7 \cdot 4$ \\
\hline & II & $8 \cdot 72$ & $7 \cdot 34$ & $<2 \cdot 70$ & $<2 \cdot 70$ & $<1.70$ & $6 \cdot 2$ \\
\hline \multirow[t]{2}{*}{$1 \mathrm{D}$} & I & 8.62 & $7 \cdot 75$ & $<2.70$ & $<2 \cdot 70$ & 6.56 & 4.8 \\
\hline & II & $7 \cdot 88$ & $5 \cdot 11$ & $<2.70$ & $5 \cdot 49$ & $<1 \cdot 70$ & $6 \cdot 6$ \\
\hline \multirow[t]{2}{*}{$2 \mathrm{~A}$} & I & $7 \cdot 32$ & $4 \cdot 18$ & $<2.70$ & $<2 \cdot 70$ & $<1.70$ & $6 \cdot 8$ \\
\hline & II & $5 \cdot 79$ & $<1.70$ & $<2 \cdot 70$ & $<2 \cdot 70$ & $<1 \cdot 70$ & $7 \cdot 0$ \\
\hline \multirow[t]{2}{*}{$2 \mathrm{~B}$} & I & 8.79 & 6.41 & $<2.70$ & $<2 \cdot 70$ & $7 \cdot 08$ & $6 \cdot 6$ \\
\hline & II & $8 \cdot 30$ & $<1.70$ & $<2 \cdot 70$ & $<2.70$ & $<1.70$ & $7 \cdot 4$ \\
\hline \multirow[t]{2}{*}{$2 \mathrm{C}$} & I & 8.78 & $2 \cdot 72$ & $<2 \cdot 70$ & $<2.70$ & $<1.70$ & $6 \cdot 8$ \\
\hline & II & $7 \cdot 40$ & $<1.70$ & $<2 \cdot 70$ & $<2 \cdot 70$ & $<1.70$ & $6 \cdot 6$ \\
\hline \multirow[t]{2}{*}{$2 \mathrm{D}$} & I & 8.57 & $7 \cdot 29$ & $4 \cdot 00$ & $<2 \cdot 70$ & $<1.70$ & $5 \cdot 8$ \\
\hline & II & $7 \cdot 32$ & $5 \cdot 20$ & $<2 \cdot 70$ & $<2 \cdot 70$ & $3 \cdot 18$ & $5 \cdot 6$ \\
\hline \multirow[t]{2}{*}{$3 \mathrm{~A}$} & I & $8 \cdot 75$ & $7 \cdot 11$ & $<2 \cdot 70$ & $<2 \cdot 70$ & $6 \cdot 94$ & $6 \cdot 6$ \\
\hline & II & 8.53 & $<1.70$ & $<2 \cdot 70$ & $<2 \cdot 70$ & $<1 \cdot 70$ & 8.0 \\
\hline \multirow[t]{2}{*}{$3 B$} & I & 8.68 & $7 \cdot 45$ & $<2.70$ & $<2 \cdot 70$ & 6.98 & $6 \cdot 6$ \\
\hline & II & $8 \cdot 68$ & $<1 \cdot 70$ & $<2 \cdot 70$ & $<2 \cdot 70$ & $5 \cdot 70$ & $8 \cdot 4$ \\
\hline \multirow[t]{2}{*}{$3 \mathrm{C}$} & I & 8.62 & 6.51 & $<2 \cdot 70$ & $<2 \cdot 70$ & $6 \cdot 64$ & $6 \cdot 6$ \\
\hline & II & $8 \cdot 49$ & $<1.70$ & $<2 \cdot 70$ & $<2 \cdot 70$ & $2 \cdot 30$ & $7 \cdot 4$ \\
\hline \multirow[t]{2}{*}{$3 \mathrm{D}$} & I & $8 \cdot 75$ & 6.83 & $<2.70$ & $<2.70$ & $6 \cdot 85$ & $6 \cdot 6$ \\
\hline & II & 8.86 & $<1 \cdot 70$ & $<2 \cdot 70$ & $<2.70$ & $<1.70$ & 8.2 \\
\hline
\end{tabular}

a See Table 1 for explanation of sample codes.

${ }^{b} \mathrm{I}=$ tempe made with neutral soya-beans; $\mathrm{Il}=$ tempe made with soya-beans acidified by fermentation.

tion of tempe reported earlier (Nout et al. 1987a).

From the point of view of acceptability, the best tempe quality was obtained using starter derived from rice (3) and acidified beans (II). Other variations did not result in significant effects on tempe acceptability except for starters made using procedure (D) in combination with neutral beans (I), which resulted in poor acceptability.

The acceptability of tempe can be associated with a combination of various factors, including:

(1) Fermentative acidification of the substrate, which results in significantly better acceptability and lower counts of non-lactic acid bacteria. This cannot be fully explained by the direct effect that lower non-lactic acid bacteria counts have on increased acceptability; curvefitting resulted in a coefficient of determination $r^{2}=0.45$.

(2) Counts of potentially spoilagecausing microorganisms in the starter. No significant relationship was found between total aerobic count or the total of all counts in the starters and the acceptability scores of the resulting tempe.

(3) Nature of bacteria present in the starter. Note that in cases 2 (soya-bean) and 3 (rice) the best acceptability was achieved with cross-contaminated starters. From Table 1 it appears likely that lactic acid bacteria, dominating the bac- 
terial flora of the B starters, contribute to the acceptability of the finished tempe. Although similar results had been reported by us (Nout et al. 1987a) with pure cultures of lactobacilli, it is interesting to note that cross-contamination has the potential to give similar effects.

In conclusion, it was found that the microbiological composition of the starters is influenced by the nature of the raw material, prevailing acidity and $\mathrm{pH}$ combination, previous fermentation, and additional cross-contamination during starter manufacture.

The bacteriological composition and acceptability of fresh tempe was primarily influenced by initial fermentative acidification of the substrate, and also by the addition of certain lactic acid bacteria from fermenting soak water. On the other hand, the microflora of fresh tempe was not influenced significantly by the substrate (i.e. rice or soya-beans) used for starter manufacture.

\section{References}

Berghofer, E. (1987) Nutzung aussereuropaeischer, fermentierter Lebensmittel fuer heimische Zwecke. Nutrition/Ernaehrung 11, 14-22.

Djurtoft, R. and Nielsen, J. P. (1983) Increase in some B vitamins, including B12, during fermentation of tempeh, produced from cowpeas or soya-beans. J. Plant Foods 5, 135-141.

Hesseltine, C. W. (1965) A millenium of fungi, food and fermentation. Mycologia 57, 149-197.

Hesseltine, C. W., Swain, E. W. and Wang, H. L. (1976) Production of fungal spores as inocula for oriental fermented foods. Dev. Ind. Microbiol. 17, 101-115.

Ko, S. D. (1985) Some microbiological aspects of tempe starters. Proceedings, Asian Symposium on Non-salted Soybean Fermentation, Tsukuba, Japan, July 1985, pp. 101-109.

Ko, S. D. and Hesseltine, C. W. (1979) Tempe and related foods. In Economic microbiology, Vol. 4, Microbial biomass (Ed. Rose, A. H.), pp. 115-140. London, Academic Press.

Leviton, F. (1984) Tofu and tempeh packaging and shelf-life. Soyfoods 6(1), 10-11.

Lindajati Tanuwidjaja and Roestamsjah. (1985) Preparation and utilization of powder form inoculum for tempe fermentation. ASEAN Food $J .1(1), 22-24$.

Nout, M. J. R., Bonants- van Laarhoven, T. M. G., de Dreu, R. and Gerats, I. A. G. M. (1985) The influence of some process variables and storage conditions on the quality and shelf-life of soya-bean tempeh. Antonie van Leeuwenhoek 51, 532-534.

Nout, M. J. R., de Dreu, M. A., Zuurbier, A. M. and Bonants-van Laarhoven, T. M. G. (1987a) Ecology of controlled soyabean acidification for tempe manufacture. Food Microbiol, 4, 165-172.

Nout, M. J. R., Beernink, G. and Bonants- van Laarhoven, T. M. G. (1987b) Growth of Bacillus cereus in soya-bean tempeh. Int. J. Food Microbiol. 4, 293-301.

Nout, M. J. R., Notermans, S. and Rombouts, F. M. (1989) Effect of environmental conditions during soya-bean fermentation on the growth of Staphylococcus aureus and production and thermal stability of enterotoxins A and B. Int. J. Food Microbiol. In press.

Samson, R. A., van Kooij, J. A. and de Boer, E. (1987) Microbiological quality of commercial tempeh in the Netherlands. J. Food Protect 50(2), 92-94.

Shurtleff, W. and Aoyagi, A. (1979) The book of tempeh. Harper \& Row, New York.

Soetarno Hadisepoetro, E. S., Nobuo Takada and Yasuji Oshima. (1979) Microflora in ragi and usar. J. Ferment. Technol. 57(4), 251-259.

Steinkraus, K. H. (1978) Tempeh - an Asian example of appropriate/intermediate food technology. Food Technol. 32(4), 79-80.

Steinkraus, K. H., van Buren, J. P., Hackler, L. R. and Hand, D. B. (1965) A pilot-plant process for the production of dehydrated tempeh. Food Technol. 19(1), 63-68.

Wang, H. L. (1984) Tofu and tempeh as potential protein sources in the western diet. J. Am. Oil Chem. Soc. 61, 528-534.

Wang, H. L., Swain, E. W. and Hesseltine, C. W. (1975) Mass production of Rhizopus oligosporus spores and their application in tempeh fermentation. J. Food Sci. 40, 168-170. 